\title{
Detection of genetically modified maize events in Brazilian maize-derived food products
}

Maria Regina BRANQUINHO ${ }^{1 *}$, Déborah Márcia Vasconcelos GOMES², Renata Trotta Barroso FERREIRA ${ }^{1}$, Rafael LAWSON-FERREIRA ${ }^{1}$, Paola CARDARELLI-LEITE ${ }^{1}$

\begin{abstract}
The Brazilian government has approved many transgenic maize lines for commercialization and has established a threshold of $1 \%$ for food labeling, which underscores need for monitoring programs. Thirty four samples including flours and different types of nacho chips were analyzed by conventional and real-time PCR in 2011 and 2012. The events MON810, Bt11, and TC1507 were detected in most of the samples, and NK603 was present only in the samples analyzed in 2012. The authorized lines GA21, T25, and the unauthorized Bt176 were not detected. All positive samples in the qualitative tests collected in 2011 showed a transgenic content higher than $1 \%$, and none of them was correctly labeled. Regarding the samples collected in 2012, all positive samples were quantified higher than the threshold, and $47.0 \%$ were not correctly labeled. The overall results indicated that the major genetically modified organisms detected were MON810, TC1507, Bt11, and NK603 events. Some industries that had failed to label their products in 2011 started labeling them in 2012, demonstrating compliance with the current legislation observing the consumer rights. Although these results are encouraging, it has been clearly demonstrated the need for continuous monitoring programs to ensure consumers that food products are labeled properly.
\end{abstract}

Keywords: GMO; real-time PCR; transgenic maize; food labeling.

\section{Introduction}

Brazil is the second largest adopter of biotech crops in the world with 36.6 million hectares (JAMES, 2012), of which around 24 million hectares were planted with glyphosatetolerant soybean, 0.5 million hectares with genetically modified cotton, and 12 million hectares with genetically modified maize (CÉLERES, 2012).

Since 2007,18 genetically modified (GM) maize events have been approved for commercialization in Brazil by the National Biosafety Technical Commission (COMISSÃO..., 2012) and, currently, the main commercial transgenic lines are TC1507, MON810, MON89034, Bt11, MIR162 for insect resistance, and NK603 and GA21 for glyphosate tolerance (CRUZ; QUEIROZ; PEREIRA FILHO, 2012).

Brazilian regulation requires that all foodstuffs for human consumption that contain a limit of $1 \%\left(10 \mathrm{~g} . \mathrm{Kg}^{-1}\right)$ of approved genetically modified organisms provide this information on the label (Decree No. 4860 of April 2003 (BRASIL, 2003)) to ensure that consumers are properly informed about the presence of genetically modified ingredients in the food products. Since then, some studies on the detection and quantification of levels of genetically modified soybean and maize in Brazilian food products have been published (BRANQUINHO; FERREIRA; CARDARELLI-LEITE, 2010; BROD et al., 2007; BROD; ARISI, 2008; CARDARELLI et al., 2005; DINON et al., 2010; FERREIRA; BRANQUINHO; CARDARELLI-LEITE, 2009; GREINER; KONIETZNY, 2008; MARCELINO; GUIMARÃES; BARROS, 2007). The methods used are based on the Polimerase Chain Reaction (PCR), which is the analytical system widely adopted in GMO detection, and the quantifications are based on real-time PCR (qPCR) that targets different genetic elements, including the cauliflower mosaic virus $35 \mathrm{~S}$ promoter (P-35S) (VAN DEN EEDE, 2010).

Efforts have been made by Brazilian health regulatory authorities to enforce both food safety and food labeling policies. Regarding GMO, some monitoring programs have been established to detect and quantify the content in food products containing soybean and maize. The present study was based on a monitoring program with the aim to detect the presence and quantify the content of the approved maize events MON810, Bt11, TC1507, NK603, GA21, and T25 in Brazil, in products containing maize collected by health authorities from food markets in order to verify the compliance with labeling requirements. The presence of the unapproved event Bt176, already authorized in Argentina, North America, Asia, and Europe (CENTER..., 2012) was also evaluated.

The analyses were performed at the Reference Laboratory of the Ministry of Health (National Institute for Quality Control in Health - INCQS), which is responsible for providing support for surveillance activities undertaken by health authorities.

\section{Materials and methods}

\subsection{Samples and standards}

A total of 34 samples of Brazilian origin were analyzed: 16 samples of maize flours in 2011 and 16 samples of maize flours

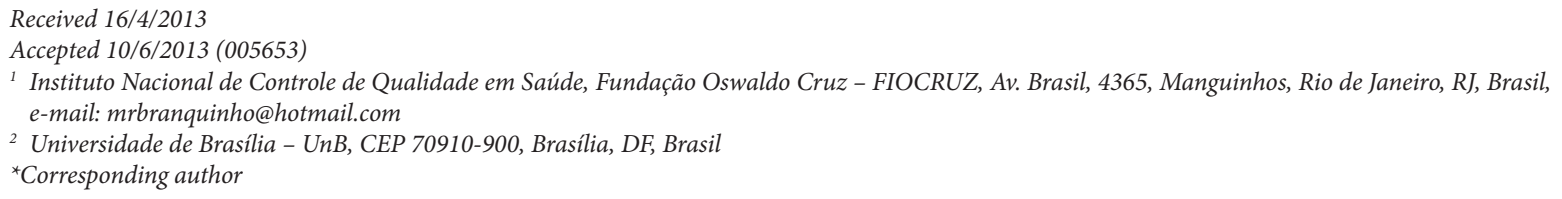


and 02 samples of nacho chips in 2012. These samples comprised 13 different brands and were gathered randomly from markets in Rio de Janeiro state by regulatory health authorities of Rio de Janeiro as part of monitoring program.

Certified reference materials (CRMs) consisting of dried maize flour with 1, 5, 10, 20, and $50 \mathrm{~g} . \mathrm{Kg}^{-1}$ of MON 810 maize (ERM 413), 0 and $10 \mathrm{~g} . \mathrm{Kg}^{-1}$ of GA 21 maize (ERM 414), 0 and 10 g. $\mathrm{Kg}^{-1}$ of Bt 176 (ERM 411), and 0 and $10 \mathrm{~g} \cdot \mathrm{Kg}^{-1}$ of Bt 11 (ERM 412), developed by the Institute for Reference Materials and Measurements (IRMM, Geel, Belgium) and commercialized by Fluka BioChemika, were used as standards in the analyses.

\subsection{Sample preparation and DNA extraction}

A total of $1 \mathrm{~kg}$ of samples consisting of 1-2 packages were manually homogenized with the exception of nacho chip samples which were ground in an M20 Mill (IKA Works, Inc., Wilmington, CA, USA) under carefully controlled conditions to avoid cross-contamination among samples. DNA was extracted in triplicate from $100 \mathrm{mg}$ of homogenized samples and CRMs using the CTAB (cetyltrimethyl ammonium bromide) method according Lipp et al. (1999). All DNA extractions were resuspended in 50-100 $\mu \mathrm{L}$ of DNA grade water and stored at $-20{ }^{\circ} \mathrm{C}$. DNA concentrations and purity were estimated by the Gene Quant pro spectrophotometer (Amersham Biosciences, Piscataway, NJ).

\subsection{Detection of specific GMO (MON810, Bt176, Bt11, and GA21) using conventional PCR}

The amplificability of DNA extracted was verified using the primers ZE01/ZE02 specific to intrinsic maize gene zein (Ze 1) detection to confirm the presence and quality of DNA extracted from maize-containing samples (MATSUOKA et al., 2000).

The samples with positive signal for zein gene were analyzed for detection of the E35S promoter/hsp70 exon-intron cassette of MON 810 maize by nested PCR using the primer pairs mg1/mg2 and mg3/mg4 (ZIMMERMANN et al., 1998); for detection of the synthetic cryIA (b) gene derived from $B$. thurigienses for identification of Bt176 maize by nested PCR using the primer pairs CRYIA1/CRYIA2 and CRYIA3/CRYA4 (STUDER et al., 1997); and for detection of the junction of the maize adh 1S-intron2 (IVS2) and the pat gene from Streptomyces viridochromogenes for identification of Bt11 maize using the primer pair Intron IVS2-2/PAT (INTERNATIONAL..., 2005). The same samples were also analyzed for detection of GA21 using the primers pair GA21 3-5'/GA21 3-3' (KURIBARA et al., 2002). Primers, PCR conditions, and amplicon length were described in the references. Primers were synthesized and purified by Invitrogen Brasil (Life Technologies Brazil).

\subsection{Quantification of P-35S target}

A duplex reaction was performed using the TaqMan ${ }^{\circledast}$ GMO 35S Maize detection kit (Applied Biosystems) for amplification of the maize zein gene target and the P35S target in the same tube. The P35S system's probe is a 5'FAM-labeled probe, while the probe for zein is a 5'VIC-labeled probe. The quencher dye
TAMRA is located on the 3'-end of both probes. Details about primers and probe sequences, amplicon sizes, and chemical concentrations were not provided within the kit. The reactions were carried out in 96-well microtiter plates in a total volume of $25 \mu \mathrm{L}$ containing $22 \mu \mathrm{L}$ master mix, $0.5 \mu \mathrm{L}$ AmpliTaq Gold ${ }^{\circledR}$ polymerase and $2.5 \mu \mathrm{L} \mathrm{DNA}$, and run on the ABI Prism ${ }^{\circledast} 7500$ Sequence Detection System (Applied Biosystems, Foster City, CA, USA), according to the following thermal cycling protocol: initial step at $95^{\circ} \mathrm{C}$ for 10 minutes and 45 cycles at $95^{\circ} \mathrm{C}$ for 20 seconds and $60{ }^{\circ} \mathrm{C}$ for 1 minute. All products and reagents were purchased from Applied Biosytems.

Calibration curves were obtained using the DNA extracted from ERM 413 (0, 1, 5, 10, 20 and 50 g. $\mathrm{Kg}^{-1}$ MON 810 maize) run in triplicate using the $\Delta \mathrm{Ct}$ (delta $\mathrm{Ct}$ ) method. The differences between the $\mathrm{Ct}$ values of the P35S and the zein sequences $\left(\Delta \mathrm{Ct}=\mathrm{Ct}{ }_{\text {GMo }}-\mathrm{Ct}{ }_{\text {zein }}\right)$ were calculated for each standard concentration and plotted against the logarithm of the GMO concentration expressed as a percentage. The P35S percentage was calculated from the $\Delta \mathrm{Ct}$ values derived from the linear regression equation of the calibration curve.

The efficiency of the PCR reaction and the linearity of calibration curves were evaluated according ENGL specifications (EUROPEAN..., 2008). To check the reproducibility of $\mathrm{Ct}$ measurements, each concentration of DNA extracted from CRMs ( 100 ng) was submitted to five different runs and analyzed in triplicate. The absolute limit of detection (LOD) and the absolute limit of quantification (LOQ) were estimated by diluting DNA extracted from $50 \mathrm{~g} . \mathrm{Kg}^{-1} \mathrm{CRM}$ MON810 with DNA extracted from $0 \mathrm{~g} \cdot \mathrm{Kg}^{-1} \mathrm{CRM}$ MON810, on the basis of the maize genomic size (1C) (BENETT; LEITCH, 2004) to obtain approximately $1850,462,115,58,29,15$, and 7.5 copies of MON810 maize per $25 \mu \mathrm{L}$ volume of PCR reaction. Each dilution was analyzed in duplicate in four runs.

\subsection{Quantification of MON810, Bt11 events and detection/ quantification of NK603, TC 1507, and T25 events using real-time PCR}

The quantification of MON810 and Bt11 was performed using kits produced by Eurofins GeneScan: GMOQuant (HR) Event MON810 and GMOQuant (HR) Bt11/Bt10 Corn, respectively; and the detection/quantification of T25, TC1507 and NK603 was performed using GMOQuant (HR) LibertyLink $^{\text {Tw }}$ Corn, GMOQuant (HR) Event TC 1507 Corn, and GMOQuant (HR) Event NK603 Corn, respectively.

The kits use two single systems, one for detection of corn species (reference) and the other for GMO detection. The systems for detection of MON810, Bt11, T25, and TC1507 were construct-specific, and that for detection of NK603 was event-specific. DNA segments were amplified with two specific primers and the probes were 5'-FAM-labeled and 3'-TAMRAlabeled as quencher. The reactions were performed according to the kit manufacturer's specification. The thermocycler conditions were the same for all runs: initial step at $95^{\circ} \mathrm{C}$ for 10 minutes and 45 cycles at $95^{\circ} \mathrm{C}$ for 15 seconds and $60^{\circ} \mathrm{C}$ for 1 minute. 
Two calibration curves were generated, one with the GMO system and the other with the species reference system; and for each curve, four calibration points were determined with the calibration DNA standards included in the kit. The percentage of GMO DNA in the unknown DNA sample was calculated by relative quantification. The efficiency of the PCR reaction and the linearity were evaluated for each target.

\section{Results and discussion}

\subsection{DNA extraction and detection of specific GMO events}

The CTAB method was efficient providing good quality and quantity DNA preparations from all samples with a yield of around $80 \mathrm{ng} . \mu \mathrm{L}^{-1}$, measured by UV-spectrophotometry. The amplificability of the DNA extracted was confirmed through visualization of $329 \mathrm{bp}$ amplicon corresponding to maize zein gene sequence amplification.

A total of 34 maize-containing products collected in 2011 and 2012 were analyzed for specific detection of MON810, Bt11, GA21, and Bt176 using conventional PCR, and real-time PCR was used for detection of TC1507, NK603, and T25 maize. The LOD of MON810, Bt11, GA21, and Bt176 was estimated to be 1 g. $\mathrm{Kg}^{-1}$ under the PCR conditions used and the LOD of TC1507 and NK603 was estimated as 40 copies by real-time PCR. Thirteen (81.2\%) out of 16 samples of maize flours collected in 2011 showed amplicons of 149bp and 189bp, indicating the presence of MON810 and Bt11 respectively and amplification of TC1507 using real-time PCR. Only 2 samples (12.5\%) tested positive for NK603 using qPCR. No GA21, T25, and Bt176 maize events were detected.

In 2012, 16 samples of maize flours, and 02 samples of nacho chips were analyzed. Fourteen maize flour samples tested positive for MON810, Bt11, and TC1507 events, and $10(62.5 \%)$ out of these 14 samples also tested positive for NK603, demonstrating a great increase in the presence of this genetically modified crop in food Brazilian industry. One maize flour sample was positive for MON810 and TC1507, one maize flour sample was positive only for TC1507, and one nacho chip sample tested positive only for MON810 event. The other nacho chip sample tested negative for all events. No GA21, T25, and Bt176 were detected. These results are summarized in Figure 1.

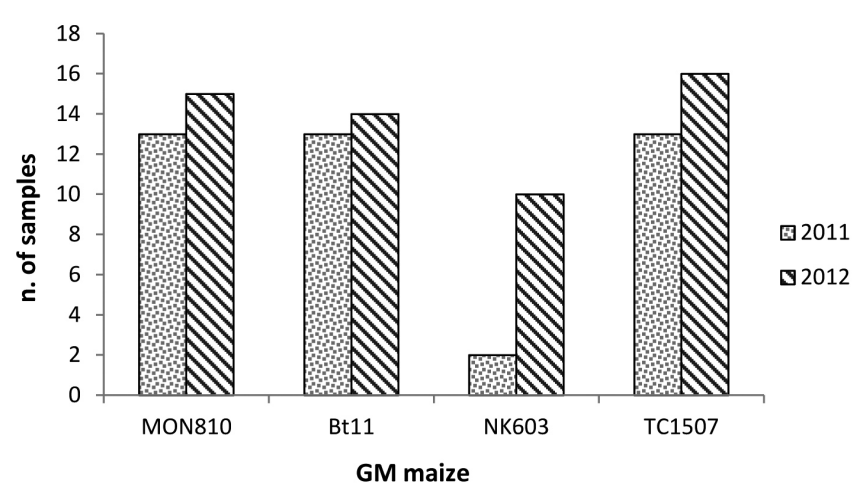

Figure 1. Number of food samples tested positive for the presence of MON810 maize, Bt11 maize, NK603 maize and TC1507 maize in 2011 and 2012.
In Brazil, some studies have attempted to detect transgenic material in food product containing maize even before the first marketing authorization of genetically modified maize in 2007. Cardarelli et al. (2005) did not detect MON810 and Bt176 maize in pasta and pet food samples. Dinon, De Melo and Arisi (2008) and Dinon, Bosco and Arisi (2010) did not find Bt11, Bt176 and MON810 either in maize flour, corn meal, maize flour flakes, and polenta samples sold in Brazilian markets from 2005 to 2007. Greiner and Konietzny (2008) published data on 100 processed products containing maize that were analyzed every year from 2000 to 2005 and found $8 \%$ of the samples positive for Bt176, Bt11, MON810, and T25 maize. The difference between these studies might be explained by the inclusion of imported products used in these studies since the majority of the positive food products were not of Brazilian origin. Moreover, data published by Marcelino, Guimarães and Barros (2007) indicated the presence of Bt11 in few samples of corn starch and maize flours in 2004 and 2005.

The overall results of the present study indicated the major GMO events detected in the samples collected in 2011 and 2012 were as follows: MON810, TC1507, Bt11, and NK603, which allowed a good estimate of the most abundant GMO maize in the market nowadays. These findings are in agreement with data published by Brazilian Agricultural Research Corporation (EMBRAPA) regarding the currently genetically modified cultivars in the Brazilian market: TC1507, MON810, NK603, Bt11, GA21, MIR162, and MON89034 (CRUZ; QUEIROZ; PEREIRA FILHO, 2012). These GMO have been reported to be commercialized on a large scale, mainly in Spain, North, and South America countries (KLUGA et al., 2012). The events MON89034 and MIR 162 were not evaluated in the present study due to lack of calibrators in our laboratory.

\subsection{Quantification of P-35S target using real-time PCR for the evaluation of compliance with labeling legislation}

MON810, Bt11, NK603, and TC1507 maize lines contain the promoter $\mathrm{P}-35 \mathrm{~S}$ as part of their genetic modification, and this element was quantified to evaluate the compliance with labeling legislation. The transgenic content of 13 samples collected in 2011 and 17 samples collected in 2012 was determined in triplicate analyses using the TaqMan ${ }^{\circ} \mathrm{GMO} 35 \mathrm{~S}$ Maize detection kit.

The efficiency of $\mathrm{P} 35 \mathrm{~S}$ and $z$ ein amplification was evaluated by the slope of the calibration graph in five $\Delta \mathrm{Ct}$ different curves $\left(\Delta \mathrm{Ct}=\mathrm{Ct}_{\mathrm{GMO}}-\mathrm{Ct}_{\text {zein }}\right)$ using CRM MON810, and the values ranged from -3.3762 to -3.5806 corresponding to 97.7 to $90.2 \%$, respectively. The $\mathrm{R}^{2}$ values obtained in these runs ranged from 0.980 to 0.992 , higher than the minimum acceptable coefficient of 0.980 (EUROPEAN..., 2008). The reproducibility of Ct measurements of each target was checked in five runs using CRM MON810, and the maximum coefficient of variation for the transgenic target was $1.8 \%$ and for the endogenous system was $2.1 \%$. The LOD was determined as the lowest amount of MON810 detected in all replicates, 7.5 copies, corresponding to a relative LOD of $0.19 \mathrm{~g} \mathrm{Kg}^{-1}$. The absolute LOQ was estimated to be 30 copies of template and the LOQ relative was $0.78 \mathrm{~g} \mathrm{Kg}^{-1}$. All of these results indicated that the commercial kit and the 
Table 1. Range of content of MON810 maize, Bt11 maize, NK603 maize, and TC1507 maize in Brazilian food products analyzed in 2011 and 2012.

\begin{tabular}{|c|c|c|c|c|c|c|}
\hline Sample & Year & $\begin{array}{c}\text { Number } \\
(\mathrm{n})\end{array}$ & $\begin{array}{c}\text { MON810 } \\
\left(\mathrm{g} . \mathrm{Kg}^{-1}\right)\end{array}$ & $\begin{array}{c}\text { Bt11 } \\
\left(\mathrm{g} . \mathrm{Kg}^{-1}\right)\end{array}$ & $\begin{array}{l}\text { NK603 } \\
\left(\mathrm{g} . \mathrm{Kg}^{-1}\right)\end{array}$ & $\begin{array}{l}\text { TC1507 } \\
\left.\text { (g. } \mathrm{Kg}^{-1}\right)\end{array}$ \\
\hline Maize flour & 2011 & 3 & $18-117.5$ & $17-140$ & $0.01-0.09$ & $>500$ \\
\hline Maize flour & 2011 & 10 & $0.6-200$ & $1.4-83.5$ & ND & $>500$ \\
\hline Maize flour & 2012 & 1 & 19 & ND & ND & 210 \\
\hline Maize flour & 2012 & 4 & $12.6-53$ & $6.1-47.8$ & ND & $124-210.8$ \\
\hline Maize flour & 2012 & 10 & $13.1-47$ & $0.2-221.5$ & $0.02-64$ & $52.2-220$ \\
\hline Maize flour & 2012 & 1 & ND & ND & $\mathrm{ND}$ & $>500$ \\
\hline Nacho & 2012 & 1 & 200 & ND & ND & ND \\
\hline
\end{tabular}

ND - not detected.

laboratory conditions were suitable for duplex amplification of low percentages of GMOs with a high degree of reliability.

With regards to the samples collected in 2011, all 13 positive samples in the conventional PCR tests showed a transgenic content higher than $10 \mathrm{~g} . \mathrm{Kg}^{-1}$, and none of them was correctly labeled. These samples comprised 10 different brands. As for those collected in 2012, all 17 GMO positive samples, comprising 8 different brands, were quantified as higher than 10 g. $\mathrm{Kg}^{-1}$, most of them above $50 \mathrm{~g} \mathrm{Kg}^{-1}$. Eight (47.0\%) samples had no information on the label, and 9 samples $(52.9 \%)$ were correctly labeled with the information of the presence of genetically modified maize. The interesting fact is that some brands that failed to label their products commercialized in 2011 started labeling them in 2012, demonstrating compliance with the current legislation observing the consumer rights.

All monitoring studies on genetically modified maize in Brazilian products previously published demonstrated no compliance with the Decree 4.680/2003 (GREINER; KONIETZNY, 2008; MARCELINO; GUIMARÃES; BARROS, 2007).

\subsection{Quantification of MON810, Bt11, NK603, and TC1507 events using real-time PCR}

Kits produced by Eurofins GeneScan were used to quantify the events MON810, Bt11, NK603, and TC1507 to determine the content of each event present in the samples.

The linearity of the calibration curves and the efficiency of the real-time PCR in the quantification of each event were evaluated for each target. $\mathrm{R}^{2}$ values obtained in all runs ranged from 0.984 and 0.999 , and the slope of the curves ranged from -3.1234 to -3.6384 , corresponding to 109 to $88 \%$ of PCR efficiency, respectively. These performance parameters are in accordance with ENGL (EUROPEAN..., 2008) and indicated the suitability of these kits for detection/quantification of GMO in these food products.

Thirty samples were quantified; 13 were analyzed in 2011 and 17 in 2012. TC1507 maize was found in all maize flours samples at great levels $\left(>500 \mathrm{~g} \mathrm{Kg}^{-1}\right)$, and it is the most representative event in food products containing maize. MON810 and Bt11 events were also found in most of the samples at levels up to $200 \mathrm{~g} \mathrm{Kg}^{-1}$. NK603 was found at very low levels in a few samples collected in 2011, suggesting an adventitious contamination. Moreover, in 2012, NK603 event was found in
10 food samples at levels up to $64 \mathrm{~g} \cdot \mathrm{Kg}^{-1}$, demonstrating the intentional use of this transgenic culture. Table 1 shows the range of the content of each event according the products and the year.

\section{Conclusions}

The results obtained in the present study indicated the major GMO detected in maize-derived food products commercialized in Rio de Janeiro state in 2011 and 2012 were MON810, TC1507, Bt11, and NK603 events. The authorized lines GA21, T25, and the unauthorized Bt176 were not detected.

The real-time PCR (qPCR) allowed the quantification of each event for the evaluation of compliance with Decree $4680 / 2003$. In this study, it was found a genetically modified content much higher than the legal threshold in most of the products. None of the labels of the samples collected in 2011 provided information about the presence of GM maize. Regarding to the samples collected in 2012, $47.0 \%$ were not properly labeled. Despite the number of the analyzed samples, the important fact was that some industries that failed to label their products manufactured in 2011 started labeling their products manufactured in 2012, demonstrating the beginning of compliance with the current legislation. Although these results are encouraging, it has been clearly demonstrated the need for continuous monitoring programs to ensure consumers that food products are labeled properly.

Contributing to health promotion and disease prevention, INCQS acts as a Brazilian reference for scientific and technological issues related to quality control of products including foods, providing support for surveillance activities undertaken by health authorities in the enforcement of food safety and labeling policies in order to safeguard consumer rights.

\section{Acknowledgments}

The authors are grateful for the financial support provided by Oswaldo Cruz Foundation and the National Agency for Sanitary Surveillance (ANVISA). The samples were collected by the Department of Health Surveillance of Rio de Janeiro.

\section{References}

BENETT, M. D.; LEITCH, I. J. Plant DNA c-values databases of The Royal Botanic Garden, Kew, UK. 2004. Disponível em: <http:// www.rbgkew.org.uk>. Acesso em: dez. 2012. 
BRANQUINHO, M. R.; FERREIRA, R. T. B.; CARDARELLI-LEITE, P. Survey of compliance with labeling legislation in food containing GMOs in Brazil. Journal of Food Composition and Analysis, v. 23, p. 220-225, 2010. http://dx.doi.org/10.1016/j.jfca.2009.09.004

BRASIL. Decreto no 4689, de 24 de abril de 2003. Regulamenta o direito à informação, assegurado pela Lei no 8078 de 11 de setembro de 1990, quanto aos alimentos e ingredientes alimentares destinados ao consumo humano ou animal que contenham ou sejam produzidas a partir de organismos geneticamente modificados, sem prejuízo do cumprimento das demais normas aplicáveis. Diário Oficial da República Federativa do Brasil, Brasília, DF, 24 abr. 2003. Disponível em: <http://www.anvisa.gov.br/e-legis > Acesso em dezembro de 2012.

BROD, F. C. A.; ARISI, A. C. M. Quantification of Roundup Ready soybean in Brazilian soy-derived foods by real-time PCR. International Journal of Food Science and Technology, v. 43, p. 1027-1032, 2008. http://dx.doi.org/10.1111/j.13652621.2007.01556x

BROD, F. C. A. et al. Nested PCR detection of genetically modified soybean in soybean flour, infant formula and soymilk. LWT Food Science and Technology, v. 40, p. 748-751, 2007. http://dx.doi. org/101016/j.lwt.2005.12.2009

CARDARELLI, P. et al. Detection of GMO in food products in Brazil: the INCQS experience. Food Control, v. 16, p. 859-866, 2005. http:// dx.doi.org/101016/j.foodcont.2004.07.010

CÉLERES. Biotechnology reporting. 2nd follow-up on agricultural biotechnology adoption for the 2012/2013 crop. Disponível em: $<$ http://www.celeres.com.br>. Acesso em: dez. 2012.

CENTER FOR ENVIRONMENTAL RISK ASSESSMENT - CERA. GM Crop Database. 2012. Disponível em: <http://www.cera-gmc. org> Acesso em: fev. 2013.

COMISSÃOTÉCNICANACIONALDEBIOSSEGURANÇA-CTNBio. Commercial Approvals. 2012. Disponível em: <http://www.ctnbio. gov.br>. Acesso em: fev. 2013.

CRUZ, J. C.; QUEIROZ, L. R.; PEREIRA FILHO, I. A. Mais de 210 cultivares transgênicas são disponibilizadas no mercado de sementes do Brasil para a sagra 2012/13. Embrapa Milho e Sorgo, 2012. Disponível em <http://www.cnpms.embrapa.br/milho/ cultivares/>. Acesso em: fev. 2013.

DINON, A. Z.; BOSCO, K. T.; ARISI, A. C. M. Monitoring of Bt11 and Bt176 genetically modified maize in food sold commercially in Brazil from 2005 to 2007. Journal of Science Food Agriculture, v. 90, p. 1566-1569, 2010.

DINON, A. Z.; DE MELO, J. E.; ARISI, A. C. M. Monitoring of MON 810 genetically modified maize in foods in Brazil from 2005 to 2007. Journal of Food Composition and Analysis, v. 21, p. 515518, 2008. http://dx.doi.org/10.1016/j.jfca.2008.04.008

DINON, A. Z. et al. Monitoring of GMO in Brazilian processed meat and soy-based products from 2007 to 2008. Journal of Food
Composition and Analysis, v. 23, p. 226-229, 2010. http://dx.doi. org/10.1016/j.jfca.2009.12.002

EUROPEAN NETWORK OF GMO LABORATORIES - ENGL. Definition of Minimum Performance Requirements for Analytical Methods of GMO Testing. version 13-10-2008. Disponível em: <http://gmo-crl.jrc.ec.europa.eu/> Acesso em: julho de 2012.

FERREIRA, R. T. B.; BRANQUINHO, M. R.; CARDARELLILEITE, P. Soja geneticamente modificada em alimentos contendo farinha e preparados à base de farinha de trigo. Detecção e adequação à legislação de rotulagem. Brazilian Journal of Food Technology, v. 12, n. 3, p. 241-248, 2009. http://dx.doi.org/10.4260/ BJFT.2009800900018

GREINER, R.; KONIETZNY, U. Presence of genetically modified maize and soy in food products sold commercially in Brazil from 2000 to 2005. Food Control, v. 19, p. 499-505, 2008.

I N T E R N A T I O N A L O R G A N I Z A T I O N F O R STANDARDIZATION - ISO. ISO 21569: Foodstuffs: Methods of analysis for the detection of genetically modified organisms and derived products - qualitative nucleic acid based methods. Switzerland: ISO, 2005. 69 p. tab.

JAMES, C. Brief 44. Global status of commercialized biotech/GM crops: 2012. Disponível em: <www.isaaa.org> . Acesso em: fev. 2013.

KLUGA, L. et al. Applicability of the "Real-Time PCR-Based Readyto-Use Multi-Target Analytical Systems for GMO Detection" in processed maize matrices. European Food Research Technology, v. 234, p. 109-118, 2012.

KURIBARA, H. et al. Novel reference molecules for quantitation of genetically modified maize and soybean. Journal AOAC International, v. 85, p. 1077-1089, 2002.

LIPP, M. et al. IUPAC collaborative trial study of a method to detect genetically modified soy beans and maize in dried powder. Journal of AOAC International, v. 82, n. 4, p. 923-928, 1999.

MARCELINO, F. C.; GUIMARÃES, M. F. M.; BARROS, E. G. Detecção e quantificação de alimentos geneticamente modificados: o panorama brasileiro. Revista Ceres, v. 54, n. 313, p. 240-250, 2007.

MATSUOKA, T. et al. A method of detecting recombinant DNAs from four lines of genetically modified maize. Journal of Food Hygienic Society of Japan, v. 41, p. 137-143, 2000.

STUDER, E. et al. Detection of the genetically engineered maize using the polymerase chain reaction (PCR). Mitteilungen aus dem Gebiete der Lebensmittel und Hygiene, v. 88, p. 515-537, 1997.

VAN DEN EEDE, G. Compendium of reference methods for GMO analyses. 2010. Disponível em: <http://publications.jrc.ec.europa. eu/repository/handle/111111111/15068>. Acesso em: fev. 2013.

ZIMMERMANN, A. et al. A sensitive detection method for genetically modified MaisGard (TM) crop using a nested PCR-system. Lebensmittel-Wissenschaft \& Technologie, v. 31, p. 664-667, 1998. 